Asia Proceedings of Social Sciences

(APSS)

www.readersinsight.net/APSS

\title{
Business Model Innovation and Customer Experience Orientation: The Role of Digital Leadership
}

\author{
Leonardus Wahyu Wasono* \\ Doctor of Research in Management, Bina Nusantara University \\ Indonesia \\ Sasmoko \\ Faculty of Humaniora, Bina Nusantara University \\ Indonesia

\section{Firdaus Alamsjah} \\ Business of School, Bina Nusantara University \\ Indonesia

\section{Elidjen} \\ Business of School, Bina Nusantara University \\ Indonesia
}

*Corrosponding author's Email: leonarduswasono@gmail.com

Peer-review under responsibility of $4^{\text {th }}$ Asia International Conference 2018 editorial board (http://www.utm.my/asia/our-team/) (C) 2018 Published by Readers Insight Publisher, lat 306 Savoy Residencia, Block 3 F11/1,44000 Islamabad. Pakistan, info@ readersinsight.net This is an open access article under the CC BY-NC-ND license (http://creativecommons.org/licenses/by-nc-nd/4.0/). 


\section{Research High Iight s}

The study proposed three hypothesis on the role of digital leadership on developing business model innovation and customer experience orientation, whether the digital leadership has significant direct and indirect impact on developing business model innovation through customer experience orientation. the study is conducted with unit analysis of Indonesia telecommunication firms with 88 senior leaders were being observed. The results indicated the digital leadership there is a significant impact directly and indirecty through customer experience orientation in formulating business model innovation. The finding has implication for scholar and management in managing digital era, the digital leadership plays significant role that has implication for Indonesia incumbent firms to develop the digital leadership capability in assure managing digital transformation successfully implemented. Further study can be expanded through expand the research model, sample and statistical tool analysis

\section{Graphical A bstract}

Figure 1 show the reflection of research results based on research model, where digital leadership has significant impact directly and indirectly through customer experience orientation to business model innovation.

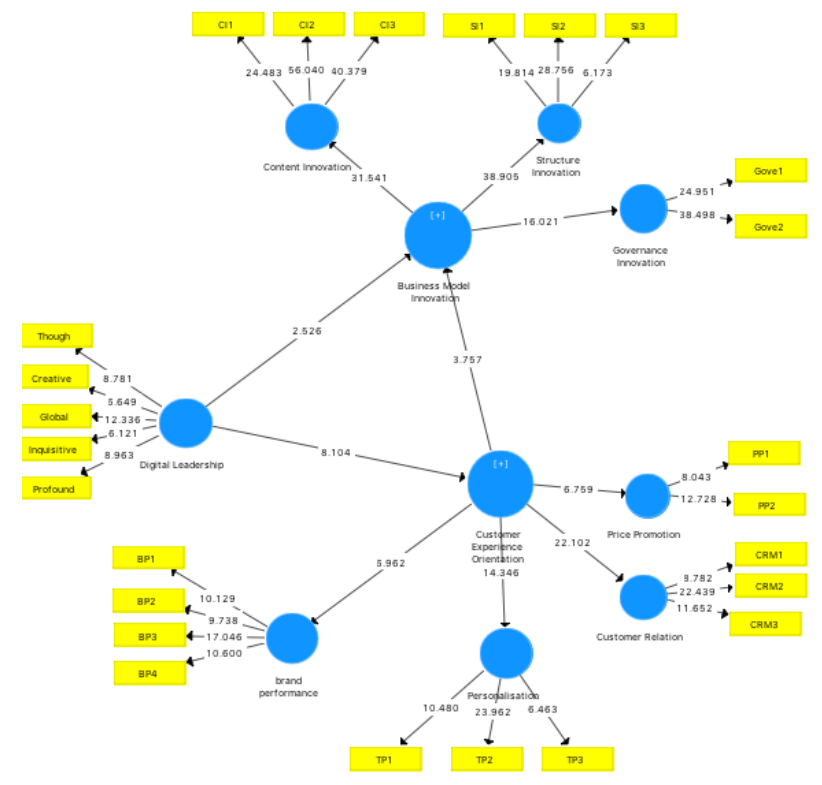

Figure 1. The Research Result 


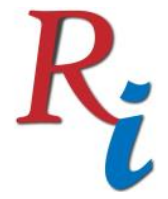

Asia Proceedings of Social Sciences

(APSS)

www.readersinsight.net/APSS

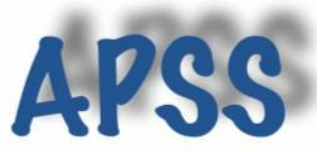

\section{Research Objectives}

Top leader is a reflection of organisation and a central in driving transformation as part of upper echelon theory (Hambrick \& Mason, 1984). In digital era, leaders face challenges with complex and dynamic ecosystem due to volatility, uncertainty, complexity and ambiguity (VUCA) factors. Due to the nature of digital, the ecosystem become interconnected, innovative, standardized, modular, interoperable, decentralized, and more focus on service oriented (Ibarra, Ganzarain, \& Igartua, 2018), hence it is requested to develop digital leadership capability. Digital transformation is required by incumbent firms, the main of digital transformation is business model innovation ( $\mathrm{Li}, 2018)$. In digital era, The development of business model innovation relly on the customer experience, since customer can be connected through digital technology anywhere and any time (Berman, 2012).

The study the role of digital leadership to drive business model and customer experience orientation has not been explored, hence this paper has aims to assess the role of digital leadership directly and directly through customer experience orientation in developing business model innovation. the study is a quantitative study through survey among the Indonesia telecommunication firms. The study is expected contributed to management practice to get the proper path in managing digital transformation model.

\section{Methodology}

The quantitative study was conducted through survey since November 2017 until January 2018. Unit analysis was Indonesia Telecommunication firms with the management of these firms as the observed unit. The study used purposive sampling. The study is conducted with 88 respondents from the identied population is made up of 445 companies including 312 Internet Service Provider (ISP) firms and network providers and its partners (34 satellite firms, 27 towers, and 72 Telkom subsidiaries and affiliates). According to research model as shown in figure 1 , there are 1 endogenous construct with 2 (two) arrow directed. Cohen (Cohen, 1992) in his research found that the minimum sample size is 33 respondents for this model with $5 \%$ Probability error, $80 \%$ statistical power and minimum R2 $=0.25$. this study with 88 sample has higher than recommendation. The distribution profile of respondents as follow: $88 \%$ respondents are men and $12 \%$ are women. while, $83 \%$ respondents come from network provider, and $17 \%$ from service providers. Data were collected through an online 


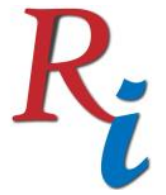

\section{Asia Proceedings of Social Sciences \\ (APSS) \\ www.readersinsight.net/APSS}

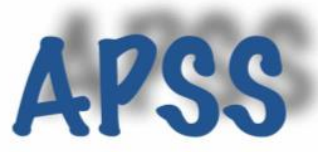

questionnaire. The data was collected through messenger, WhatsApp, Telegram and email. The statistical a tool of analysis is SmartPLS due to limitation of data collection.

\section{Results}

The statistical analysis conducted two assesment testing (Henseler, Hubona, \& Ray, 2016): (1) Mesurement model test to ensure that the relationship between latent variable and their indicators are valid. The analysis used convergent validity, composite relibility, and discriminant validity, (2) structural model and hypothesis testing to measure endegous variable and direct $\&$ indirect effect to conclude with hypothesis testing. The results indicate that in measurement testing shows that all latent variable and their indicators are valid. In the structural model testing indicats that the structural model has adequate predictive relevance. In Hypothesis testing show digital leadership has directly and indirectly inflluence through customer experience orientation to business model innovation. In direct effect, digital leadership has significant to business model innovation with coefficient score of 0.360 , tstatistics $=2.540$ and $\mathrm{p}$-value $=0.010<0.05$. It has significant impact to customer experience orientation with path coefficient score of 0.633 , t-statistics $=8.181$ and $\mathrm{p}$-value $=$ $0.000<0.05$. while customer experience orientation has signifiant impact to business innovation with the result of path coefficient score of 0.537 , t-statistics $=3.786$ and $p$-value $=0.000<0.05$.

In indirect effect test, co-creation plays as a moderating role in relationship between business model innovation and customer experience orientation.

\section{Findings}

The Digital leadership plays sigificant role in developing capabilities of business model innovation and customer experince orientation. Digital leadership is made by global, though and creative capability. This is aligned with the phenomenon of digital era where everything connected and creativity is playing significant role ( $\mathrm{Li}, 2018)$. While customer experience orientation is formed by customer relation and personalisation, this finding align with previous study where personalization of customer is part of customer journey and relation through analytical (Lemon \& Verhoef, 2016). The Business model innovation is established 


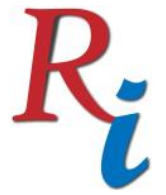

\section{Asia Proceedings of Social Sciences \\ (APSS) \\ www.readersinsight.net/APSS}

from content and structure innovation. This finding aligns with during the innovation, the performance result is more important rather than governance.

\section{References}

Berman, S. J. (2012). Digital transformation: Opportunities to create new business models. Strategy and Leadership, 40(2), 16-24. https://doi.org/10.1108/10878571211209314

Cohen, J. (1992). Quantitative Methods in psychology: A Power Primer. Psychological Bulletin, 112(1), 155-159. https://doi.org/10.1016/j.jorganchem.2011.01.025

Hambrick, D. C., \& Mason, P. a. (1984). Echelons : of Reflection The Its Organization as Top a. Academy of Management ReviewManagement, 9(2), 193-206. https://doi.org/10.2307/258434

Henseler, J., Hubona, G., \& Ray, P. A. (2016). Using PLS path modeling in new technology research: Updated guidelines. Industrial Management and Data Systems, 116(1), 2-20. https://doi.org/10.1108/IMDS-09-2015-0382

Ibarra, D., Ganzarain, J., \& Igartua, J. I. (2018). Business model innovation through Industry 4.0: A review. Procedia Manufacturing, 22, 4-10. https://doi.org/10.1016/j.promfg.2018.03.002

Lemon, K. N., \& Verhoef, P. C. (2016). Understanding Customer Experience Throughout the Customer Journey. Journal of Marketing, 80(6), 69-96. https://doi.org/10.1509/jm.15.0420

Li, F. (2018). The digital transformation of business models in the creative industries: A holistic framework and emerging trends. Technovation, (January), 1-10. https://doi.org/10.1016/j.technovation.2017.12.004 